medical press. I have looked over the rules of the Newport Infirmary and $I$ cannot find any rule giving the directors the power to dispense with the services of their honorary medical officers. Believe me, Sirs, youra faithfullv.

Dec. 8th, 1897

T. GARRE'T HoRDWR.

[STATEMENT bY Mr. Ensor.]

For more than twelve months there has been a feeling of annoyance among the honorary medical ofticers of the Newport Infirmary cansed by patients presenting themselves for treatment (and bringing subscribers' recommendations) when they are in a position to pay for what medical treat ment they require. Many of these applicants regard the charity as a medical aid society or a club, and when asked if they regard themselves as objects of charity say that they support the infirmary and have a right to its benefits-their subscription being one or two shillings or more in the course of the year.

During the present year many sabscribers' notes have been referred to the infirmary directors for inquiry, and in no instance had a reply been sent back to the writer, till the time of the present dispute which extends back to the middle of October in this year when two patients presented themselves, one the daughter of a man earning $45 \mathrm{~s}$. a week or $£ 117$ per annum. and the other a boy whose weekly earnings (including his father's) was $59 s$. per week or $£ 153$ per annum. They both came from the same works, where the firm subscribed $£ 10$ 10s. last year and the workmen $£ 612 s .11 d$. The writer declined to see these cases as he thought they were cases abusing the charity and they were not at all urgent; thus protesting against the action of the directors in jgnoring the subscribers' notes previously sent to them.

Being refused treatment these applicants caused complaints to be made to the directors (or committee), who caused a letter to be sent to the writer, calling his attention to a previous resolution of the board, viz., "that all doubtful cases are to be referred to the house committee for investigation and inquiry but in the meantime the patient must be treated." He replied protesting at being requested to see patients earning big wages. The committee ascertained that in one case the wage earner had been laid up for a few weeks and called upon him to attend the cases (writing to the applicants that they would be seen). The writer refused again hoping that by so doing the committee would adopt a wage limit or appoint an inquiry officer, and as a result he was dismissed from his appointment as ophthalmic surgeon.

About eighteen months ago a subscriber of two guineas sent a child to the infirmary whose father had a salary of $£ 100$ per annum and was refused treatment by the house committee while the cases referred to above were deemed eligible when making $£ 117$ and $£ 153$ respectively, apparently for the reason that the works refused further contributions unless the directors sent a satisfactory explanation for the rejection of the cases.

Windsor-place, Cardiff, Dec. 8th, 1897.

\section{THE IMPORTANCE OF HISTORY IN DIAGNOSIS}

To the Editors of The LANCET.

SIRS,-During the winter of 1895-96 I attended a man suffering from persistent and uncontrollable vomiting for which he had been treated for some months with all the usual remedies, but without success. He was a spare looking man with an anxious, worn expression. All his organs appeared to be healthy. His urine was natural, his temperature normal. On inquiring minutely into his history I found that ten years previously he had been in the United States of America and had worked as a labourer in a district in which malaria was somewhat prevalent, though he himself had never had an attack. For the last ten years of his life he bad lived in England, during which time he had not had any symptoms of malaria and had been in good health until a few months before I saw him when vomiting without any apparent reason commenced and had continued off and on ever since, entirely preventing him from working and making his life a misery. There were no other facts in his past history bearing on his complaint.

Taking this somewhat slender history into account together with the fact that all ordinary remedies for his symptom had falled, moderate doses of quinine were prescribed with the result that the vomiting absolutely stopped and the man returned to his work highly delighted with his recovery. He was told to continue the remedy as long as he found it necessary. The points [ would especially draw attention to in this case are : (1) that although there could be little doubt that the vomiting was malarious in origin the patient could give no history of an attack of malaria either whilst residing in a malarious district or during his subsequent ten years' residence in a healthy locality in England; and (2) the importance of history in diagnosis and as a causal indication for treatment in otherwise somewhat obscure cases. I am, Sirs, yours faitbfully,

Kastbourne, Dec. 13th, 1897 . ALEXANDER C. GURNEY, M.B. Lond.

\section{"DR. RENTOUL'S OLAIM FOR FEES FROM THE MEDICAL COUNCIL." To the Editors of THE LANOHT.}

Sins,-With reference to a letter addressed to you by Dr. Rentoul and inserted in your last week's issue, in which he characterises as "grossly untrue" a statement of Sir Dyce Duckworth " that Dr. Rentoul had got the Chief Constable of Liverpool to measure the distance from his residence to the railway station," I am directed to request that you will be good enough to insert the following copy of a letter sent to this office by Dr. Rentoul on June 5th, 1897. I am, Sirs, yours faithfully,

General Medical Council Office, 299, Oxford-
street, W., Dec. 14th, 1897. [COPY.]

“ Liverpool Constabulary Force, Hackney Carriage Department, Municipal Offices, Sir Ihomas-street, June 2nd, 1897

"Dear Sin,--I am directed by the Head Constable to acknowledge receipt of your letter and in reply to inform you that the distance from 78, Hartington-road to Lime-street Station (main entrance in Lime street) is 2 miles 370 yards and the legal cab fare is $2 s .6 d$ "I am, dear sir, your" obedient servant,

R. R. Rentoul, Esq., M.D., 78, Hartington- D. BREESE, Inspector, "Liverpool.

\section{THE VENTILATION OF HOSPITALS. To the Editors of THB LANOET.}

SIRS-I shall be greatly obliged if any of your readers who have practical experience of the forced (plenum) system of ventilation and heating as applied to hospitals will give me information on the following points : (1) what form of forced ventilation do you regard as the best? (2) is it easily managed and is it a thorough success? (3) does it ever get out of order, say, in frost? (4) do you know of any place where the system has been a failure so that it has been found necessary to give it up in favour of the ordinary methods by fires, hot air or steam, and windows, \&c.? and (5) does its adoption add much to the initial cost of a hospital? I am, Sirs, yours faithfully, JOHN W. BYERS.

Dreenagh House, Lower-crescent, Belfast, Dec, 11th, 1897.

*** The "plenum" system of ventilation as applied to hospitals was fully described in an article in THE LANCET of May 11th, 1895, p. 1203.-ED. L.

\section{THE RESULT OF THE ADOPTION OF}

\section{HOLMGREN'S TEST BY THE BOARD}

\section{OF TRADE.}

To the Editors of THE LANOWT.

SIRS,-According to the reports which have been issued Holmgren's test has been used for two years and four months by the Marine Department of the Board of Trade. Let us consider whether there has been any improvement in the results obtained since the adoption of the test. The percentages of failures in colour vision since 1885 are as follows :-1885-86, $139 ; 1886-87,112 ; 1887-88,1.01$; $1888-89,1.03 ; 1889-90,094 ; 1890-91,1.19 ; 1891-92,0.82$; 1892-93, 1.17; from June, 1893, to August, 1894, 1.27; from September, 1894, to December. 1895, 137; and from January to December, 1896, 1.02. Holmgren's test has been used since September, 1894. One of the chief 